\title{
Journal oí
}

Lingunstios

VOLUME 15

1979

Published for the

Linguistics Association of

Great Britain by

Cambridge University Press

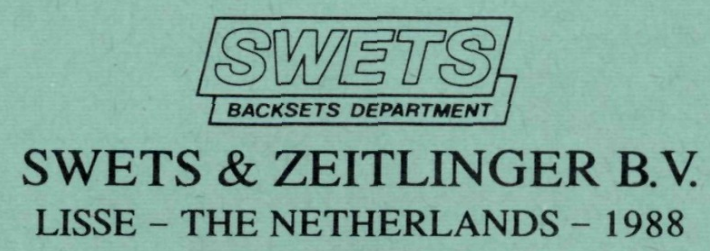




\title{
JOURNAL OF LINGUISTICS
}

VOLUME 151979

\author{
Published for the \\ Linguistics Association of \\ Great Britain by
}

CAMBRIDGE UNIVERSITY PRESS

CAMBRIDGE

LONDON NEW YORK NEW ROCHELLE

MELBOURNE SYDNEY

Reprinted with permission of the proprietors by

SWETS \& ZEITLINGER B.V.

LISSE - THE NETHERLANDS - 1988 
PUBLISHED BY

THE PRESS SYNDICATE OF THE UNIVERSITY OF CAMBRIDGE

The Pitt Building, Trumpington. Street, Cambridge CB2 IRP

32 East 57th Street, New York, N.Y. 10022

(C) Cambridge University Press 1979 


\section{CONTENTS}

\section{ARTICLES, NOTES AND DISCUSSIONS}

J. Aitchison \& G. Bailey: Unhappiness about not unhappy people

D. J. Allerton \& A. Cruttenden: Three reasons for accenting a definite subject

J. ANDERSON: Syntax and the single mother

G. G. Corbetr: The agreement hierarchy

D. A. CRUSE: On the transitivity of the part-whole relation

W. J. Edmondson: Harris on performatives

O. ERIKSSON: Scandinavian gender agreement revisited

I. FORBES: The terms brun and marron in modern standard French

B. G. HewitT: The expression of 'inferentiality' in Abkhaz

R. M. Hogg: Analogy and phonology

A. Holmberg: On whimperatives and related questions

R. Huddleston: Would have become: empty or modal will?

D. IANNuCcr: Verb triggers of Tough Movement

J. C. McLaughlin: The i-umlaut of the Old English West Saxon diphthongs (again)

D. J. NAPOLI: Reflexivization across clause boundaries in Italian

B. RoBinson \& L. HAEGEMAN: A note on some aspects of the use of WILL in affirmative declarative sentences

G. SAMPSON: The indivisibility of words

I. M. SCHLESINGER: Cognitive structures and semantic deep structures: the case of the instrumental

\section{REVIEW ARTICLE}

J. R. HURFoRD: P. M. Postal, On Raising: one rule of English grammar and its theoretical implications

J. Altchison: Linguistics (Coates)

J. Allwood, L.-G. ANdersson \& O. DahL: Logic in linguistics (Hodges)

C. A. M. Baltaxe: Foundations of distinctive feature theory (Sommerstein)

J.-P. Boons, A. GuILLET \& CH. LECLÈRE: La structure des phrases simples en francais: constructions intransitives (Durand) 


\section{CONTENTS}

R. P. Boths (with the collaboration of W. K. WINCKLER): The justification of linguistic hypotheses: a study of non-demonstrative inference in transformational grammar (Derwing)

H. E. Brekle \& D. Kastovsky (eds): Perspektiven der Wortbildungsforschung: Beiträge zum Wuppertaler Wortbildungskolloquium vom 9.-10. Fuli, 1976, anlässlich des 70. Geburtstag von Hans Marchand am I. Oktober, 1977 (Bauer)

O. BuchHolz, W. FIEdLER \& G. Uhlisch: Wörterbuch Albanisch Deutsch (Lockwood)

N. Cномsку: Essays on form and interpretation (Grosu)

G. L. Dillon: Introduction to contemporary linguistic semantics

(Cruse)

N. DITTMAR: $A$ critical survey of sociolinguistics: theory and application (Le Page)

R. M. W. Dixon (ed.): Grammatical categories in Australian languages (Robins)

J. Foley: Foundations of theoretical phonology (Coates)

V. Fromkin \& R. Rodman: An introduction to language (Horrocks)

S. Greenbaum (ed.): Acceptability in language (Sampson)

M. GRoss: Grammaire transformationnelle du franfais: syntaxe du nom (Crompton)

D. HymEs: Foundations in sociolinguistics: an ethnographic approach (Le Page)

U. JoKINEN: Les relatifs en moyen franfais: formes et fonctions (Clifford)

M. JoNEs \& A. R. ThOMAs: The Welsh language: studies in its syntax and semantics (Awbery)

J. KoRHONEN: Studien zu Dependenz, Valenz und Satzmodell (Jackson)

A. KoutsoudAs (ed.): The application and ordering of grammatical rules (Pullum)

R. K. S. Macaulay: Language, social class, and education - a Glasgow study (De Silva)

A. MalÉcot: Introduction à la phonétique française (Sharp)

K. MENNINGER: Number words and number symbols: a cultural history of numbers (Corbett)

I. M. Schlesinger \& L. NAmir (eds): Sign language of the deaf (Washabaugh)

H. SEILER: Sprache und Sprachen: gesammelte Aufsätze (Robins)

A. H. SOMMERSTEIN: Modern phonology (Roberts)

T. M. StEINFATT: Human communication: an interpersonal introduction;

Readings in human communication: an interpersonal introduction (Aitchison)

R. P. Stockwell: Foundations of syntactic theory (Gazdar) 


\section{CONTENTS}

R. P. Stockwell, D. E. Elliott \& M. C. Bean: Workbook in syntactic theory and analysis (Gazdar)

A. VALDMAN: Pidgin and creole linguistics (Washabaugh)

K. WächtLER: Geographie und Stratifikation der englischen Sprache (Kettemann)

PUBLICATIONS RECEIVED

\section{ERRATUM}

On p. 45 of Geoffrey Sampson's article 'The indivisibility of words,' in the last issue of this fournal, the phrases in italics on lines ${ }^{2} 2$ and ${ }_{3} 3$ should read 'all the wonders of the world' and 'the Wonders of the World', respectively. 